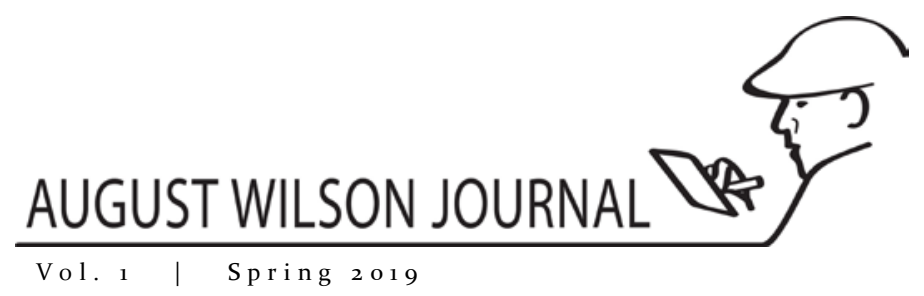

\title{
Celebrating August Wilson's Legacy in Smoketown
}

\author{
By Mark Whitaker \\ Author of Smoketown: The Untold Story of the Other Great Black Renaissance
}

Keynote Address delivered at the 2018 August Wilson Colloquium, August Wilson Center, Pittsburgh PA, April 26, 2018

\begin{abstract}
In his opening address to attendees of the August Wilson Colloquium, Mark Whitakerfrom his perspective as author of Smoketown-discusses the research he conducted and the subsequent incorporation of the topic of August Wilson into his book. Beginning with the assertion that that Wilson's family story "fits the larger pattern of migrants from the northern part of the Old South who arrived in Pittsburgh with a respect for literacy and religious discipline," Whitaker contrasts the history of black Pittsburgh as reported in the pages of The Pittsburgh Courier with the metaphorical representations in Wilson's American Century Cycle.
\end{abstract}

Keywords

August Wilson, Mark Whitaker, Smoketown, Pittsburgh Courier, Hill District

I'm very honored to be here to address this colloquium, but I'm also a bit embarrassed. I'm looking out at a room full of people who have studied August Wilson and his plays for far longer than I have. So let me begin by making clear that I don't pretend be a Wilson expert. Instead, I'm here as an author who has written a book about the larger cultural and political legacy of black Pittsburgh in the middle decades of the $20^{\text {th }}$ Century. I do address in my book, Smoketown: The Untold Story of the Other Great Black Renaissance, how Wilson, who was born at the height of that community's influence but wrote his groundbreaking plays in the decades after its economic and physical decimation, fits into that larger picture. But as far as I'm concerned, the best thing about being asked to speak first thing this morning is that I'll get to spend the rest of the day listening to real Wilson

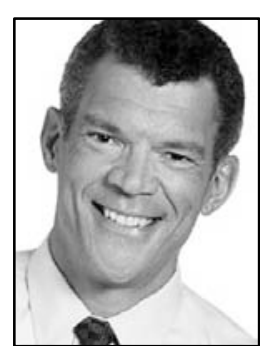

Mark Whitaker scholars and intimates.

In order to explain my perspective, it might be useful to describe how my thinking about August Wilson evolved as I was working on Smoketown. From the beginning, even before I knew exactly what shape and direction the book would take, I saw Wilson as the metaphorical elephant in the room. For two reasons. First, if readers had any sense of black Pittsburgh in the last century, it was likely because they had had seen one or more of the nine plays that Wilson set in the Hill District. In that sense, it was as though I was setting out to write a book about Danish politics at the turn of the $17^{\text {th }}$ Century. An original enough sounding project-expect for the fact that a genius named Shakespeare wrote a play about it called Hamlet.

Second, I knew that I would have to grapple with the fact that for all their extraordinary power and sweep, Wilson's Century Cycle plays ignore important segments of 
black Pittsburgh in the decades on which I planned to focus. Even before I began my research, I knew this from my father's family, which because they were middle-class business people Wilson would have viewed with distrust. When asked why his plays were populated almost exclusively by struggling members of the working class, Wilson made no bones about the fact that he considered them more culturally authentic than middle-class blacks. "America offers blacks a contract that says, 'If you leave all that African stuff over there and adopt the values of the dominant culture, you can participate," he once told literary scholar Bonnie Lyons. "The ones who accept go on to become part of the growing middle class and in some areas even acquire some power and participation in society, but when they finally settle where they arrive, they are no longer the same people. They are clothed in different manners and ways of life, different thoughts and ideals. They've acculturated and adopted white values."

Although my father's family was middle class, I knew their story hardly fit that description. Like a character in one of Wilson's plays, my grandfather, Cleophaus Sylvester Whitaker Sr., the eleventh child of former slaves from Texas, arrived in Pittsburgh as a teenager in the first wave of the Great Migration, around the time of World War I. He started out working in lowly jobs in the steel mills and as a chauffeur for a white undertaker, and may well have roomed in boarding houses like the one in Joe Turner's Come and Gone. But then Grandad went into the mortician business himself and became relatively prosperous. Never rich and rapacious like the undertaker West in Two Trains Running-in fact, Granddad eventually had to moonlight selling milk and shining shoes in a white country club-but, for a time, relatively prosperous.

My grandmother, Edith McColes Whitaker, was the only child of "OP's," or "Old Pittsburghers," as the black folks who arrived before the Great Migration were called. Her father, John McColes, worked as a steel company messenger, and her mother Emma-whom I would know as "Gram"-was a homemaker. They were hardly rich, either, but they were comfortable enough to live in Sugartop, then the most expensive neighborhood on the Hill. Grandmother Edith was a member of the first generation of black students to attend Schenley High School in the 1920's, played piano at the Carnegie Library Recital Hall and had her engagement party at the Loendi Club, the gathering place of the black elite. When the first Whitaker Funeral Home in Rankin became profitable enough, she encouraged Granddad to move it to Homewood so my father and his sisters could attend its highly regarded integrated high school, Westinghouse.

Yet my father's family was as proudly black as any other in the Pittsburgh of the day. The Grandmother I knew in my childhood cooked chitlins, played the numbers every day, went to Bethany Baptist Church on Sundays, and greeted me with down-home commands like: "Give me some sugar, child, or I'll jump down your throat and dance on your gizzard!" She also worked her arthritic knees to the bone keeping the funeral home going after Granddad suffered a stroke, and often resorted to selling Avon products door to door to pay the grocery and utility bills.

As I began to work on my book, I discovered further evidence of a black Pittsburgh not found in August Wilson's plays in the photographs of Teenie Harris. In fact, the day I decided to write the book that became Smoketown, I was browsing the internet and stumbled upon two photographs of my grandparents in the Teenie Harris Archive of the Carnegie Museum of Art. Granddad, dressed in a suit and tie and polished patent leather shoes, was presiding over the burial of a black military veteran at a graveyard outside Pittsburgh. Grandmother, wearing pearls and one of her big church hats, was attending a ladies' luncheon in Homewood.

Then, as I clicked through the rest of the archive, there was Joe Louis hanging out in the newsroom of the Pittsburgh Courier. There was Louis Armstrong grinning at a corner booth at the Crawford Grill. There was Lena Horne singing at the Loendi Club. There were Duke Ellington, Billy Strayhorn, and "Honi" Coles gathered around an upright piano at the 
Stanley Theater. There was Satchel Paige shooting the breeze with Gus Greenlee in Gus's lair atop the Crawford Grill. There was Josh Gibson squatting in a catcher's crouch in his Homestead Grays uniform. There was Jackie Robinson leaning on a bat at Forbes Field, looking right at home, during his rookie year as a Brooklyn Dodger. And on and on and on.

In other words, there on my computer screen was visual evidence of a black Pittsburgh so vibrant and influential that it was once known as "Little Harlem" and "the Crossroads of the World." Yet as I investigated further, I discovered that the full extent of that influence had been captured only in fragments, in Teenie's photographs and in individual biographies, sports and jazz books and academic studies. No one had pieced together the full story of how this relatively small black community-less than a quarter the size of Harlem's, and a third the size of Chicago's-had left such a profound imprint on Black history, and American history, in the brief but glorious period of its heyday from the 1920 's through the 1950's.

So that's the story I set out to write in Smoketown. But because I still didn't know what I was going to say about August Wilson, I put him in a box. Quite literally. You see, when I write my books I keep research materials for my chapters in separate Bankers Boxes, those cardboard storage containers you can buy at Staples or on Amazon. So I bought anthologies of Wilson's plays and collections of his interviews and put them in a box. Every time I did an interview or came across an article that touched on Wilson, I put the notepad or the clipping in the box. And I left the box untouched until I had written the rest of the book-nine chapters in all-and was finally ready to wrestle with the elephant in the room in my last chapter.

When I finally opened the August Wilson box two years later, I discovered that much of the story I had written in the rest of the book was indeed absent from his plays. As reviewers of Smoketown have noted, the heart of the book is the story of the Pittsburgh Courier, which was the best-selling black newspaper in America from the mid-thirties until the early sixties, with 14 regional editions and a circulation that peaked at more than 400,00o copies at the end of World War II. And at the heart of that story stand two Southern migrants who were extraordinary entrepreneurs. Cumberland Posey Sr., known as "Cap," was a riverboat deckhand who became the first black man to engineer a steamboat. Posey then founded a shipbuilding company and invested in coal mines and was the richest Negro in Pittsburgh when he bought stock in the Courier and became its first president in 1910. Robert Lee Vann was the son of a plantation cook from North Carolina who traveled alone to claim a scholarship for colored students at what is now the University of Pittsburgh. After becoming its first black law school graduate, Vann accepted the editorship of the Courier, and from 1910 until his death in 1940 he transformed the paper from an eight-page pamphlet of local news to the powerful national weekly it became.

Yet nowhere in Wilson's plays set in those decades do you get a sense of just how powerful the Courier was, or how much pride and swagger that gave the black folks of Pittsburgh. Seven Guitars refers to the Joe Louis's epic battle with "The Pittsburgh Kid" Billy Conn. But there is no sense of the role the Courier played in making Louis a hero to black America and a sympathetic champion to whites in the 1930's. Fences deals with Troy Maxson's bitterness at the racism that cost him a shot at pro baseball when he was playing in the Negro Leagues. But there's no hint of the part that Courier sportswriter Wendell Smith played in crusading for baseball integration, and then introducing Branch Rickey to Jackie Robinson and serving as Robinson's travel companion, confidant, and spokesman in his tense first years in the Dodgers' organization. The politics of the Depression and World War II provide a backdrop to several Wilson plays, but they don't capture how the Courier turned Pittsburgh into ground zero for the migration of black voters from the Republican to the Democratic Party under FDR, or its "Double Victory Campaign" that mobilized black support for the war after Pearl Harbor. 
While Wilson's plays are full of music and musicians-Seven Guitars and the Chicago-based Ma Rainey's Black Bottom, in particular-you wouldn't know from them that Pittsburgh produced a dozen of the greatest jazz musicians of the $20^{\text {th }}$ Century. They included not just stellar performers but trailblazers in their musical disciplines: Kenny Clarke and Art Blakey on the drums, Roy Eldridge on the trumpet, Ray Brown on the bass, George Benson on the guitar, Billy Strayhorn as a composer and arranger, and Billy Eckstine not just as crossover crooner but as a big band leader who mentored future bebop pioneers such as Dizzy Gillespie, Charlie Parker, Sarah Vaughan, Dexter Gordon, Fats Navarro and Gene Ammons.

Because my Grandmother Edith played the piano, I was particularly taken in my research with the profound impact of Pittsburgh musicians on that instrument. They include Earl "Fatha" Hines, who set a new standard for the jazz piano in his early recordings with Louis Armstrong; Mary Lou Williams, the "little piano girl of East Liberty" who grew up to become one of the greatest female instrumentalists of both the swing and the bebop eras; and Ahmad Jamal, who is performing and recording award-winning albums to this day. And, of course, Erroll Garner, who in the fifties and sixties was one of the most sought-after concert performers and late-night TV guests in the world of jazz. During his many appearances on The Tonight Show, Johnny Carson liked to kid Garner about the fact that he couldn't read music, as though he was some kind of inexplicable natural genius. But as I point out in Smoketown, Garner was simply a genius who grew up in the unique musical culture of Pittsburgh, and learned to play by ear imitating his sisters' piano teacher and his many talented classmates at Westinghouse High.

By the way, I also tell the story in the book of how we have that piano heritage to thank for one of the greatest bass players of all time. Like so many black Pittsburgh kids in his day, Ray Brown, who was born in 1926, grew up taking piano lessons. But when he arrived at Schenley High in his mid-teens, he was one of twenty-eight pianists who auditioned for the school orchestra. Ray had to wait all week just to get fifteen minutes of rehearsal time. So one day, he was waiting his turn when he spied a big string instrument in the corner of the room.

"What's that?" he asked the music teacher.

"A bass," the teacher replied.

"If I played that instrument, would I be in the orchestra all the time?" Ray asked.

"Yes, we're looking for a bass player," the teacher responded.

And that's how the great Ray Brown took up the bass!

Again, you won't find the names of Ray Brown or those legendary Pittsburgh pianists in Wilson's plays. However, I do like to think that there's at least an acknowledgement of that rich keyboard tradition embedded in The Piano Lesson. After all, Wilson said that he got the inspiration for the play from a painting by Romare Bearden, who also grew up in Pittsburgh in the era when the piano was a prized possession in so many black homes.

Despite these historical omissions, however, as I immersed myself in research about August Wilson, I came to see how firmly he stands in the broader cultural tradition I trace in Smoketown. In the introduction to the book, I talk about the three social forces that-like Pittsburgh's three great rivers-converged to make its black community so unique. The first was where the Southern migrants came from, and the kind of knowledge and values they brought with them. Second were the unique educational opportunities available to black folks in Pittsburgh in the late $19^{\text {th }}$ Century and first half of the $20^{\text {th }}$ Century, thanks to those Pitt scholarships and the Gilded Age philanthropy that helped make the city's integrated public high schools like Westinghouse and Schenley among the best-funded in America. The third was the spirit of entrepreneurship that, along with the stench from the steel plants, hung in the air in Pittsburgh, setting it apart from the more literary and less business-minded culture of Harlem. 
All three of those formative strains run deep in the August Wilson story. The rest of Smoketown is filled with characters who hailed from the northern and eastern parts of the Old South, where blacks were most likely to have learned to read books and music and to acquire other habits of cultural sophistication. As it turns out, a remarkable number came specifically from North Carolina. They include Robert L. Vann, the Courier editor; Gus Greenlee, the racketeer who owned the Crawford Grill and the Pittsburgh Crawfords; Billy Strayhorn and Mary Cardwell Dawson, the founder of America's first black opera company; and Evelyn Cunningham, the charismatic Courier reporter who covered the early battles of the Civil Rights Movement. And, sure enough, August Wilson also had North Carolina roots. His mother, Daisy, was born there and migrated to Pittsburgh in her teens with Wilson's grandmother, Zonia. In fact, it's been said that Zonia was so determined to get to Pittsburgh that she made the journey on foot-a story that, alas, my friend historian Larry Glasco assures me is apocryphal.

Daisy Wilson learned to read but Zonia never did, and the daughter watched her mother's living as a North Carolina farmer suffer as a result. So when Daisy arrived on the Hill and took up with a white German immigrant named Frederick Kittel, known as Fritz, she was determined that the children she had by him learn to read as early as possible. When her first son was born, named after his father but called "Freddy," Daisy took him to the Carnegie Library on the Hill to get a library card when he was just five years old. Soon Freddie had devoured all the Hardy Boy novels and his older sisters' Nancy Drews. With the same determination that Billy Strayhorn's mother, Lillian, showed in moving her family to Homewood so Billy could attend Westinghouse High, Daisy sent Freddie to Catholic Schools on the Hill to be taught by nuns. As a moody teen, Freddy kept getting expelled from public schools, but he had so thoroughly internalized his mother's reverence for learning that he resolved to educate himself by hiking to the Carnegie Library in Oakland every day and reading hundreds of books on its shelves.

So Wilson's story fits the larger pattern of migrants from the northern part of the Old South who arrived in Pittsburgh with a respect for literacy and religious discipline. In his own way, he was also the beneficiary of the unique opportunities for schooling-and for self-education - that were available to Pittsburgh Negroes. And if you think about it, Wilson was a shrewd businessman, too, no matter his views on capitalism. Who else but a born marketer would, after deciding to become a writer at the age of 21, type out every variation of his name to come up with a better literary moniker than Frederick Kittel Jr.? And then settle on a pen name, derived from his middle name and his mother's maiden name, that conjured both cultural distinction-Au-gust! - and Everyman ancestry-Wil-son! Who else but a natural entrepreneur would, no sooner than he had scored his first successes as a playwright, after years of struggling as a poet, decide that he wasn't going to stop until he produced a play for every decade of the $20^{\text {th }}$ Century?

As I reported and wrote Wilson's story, I couldn't help but compare his visionary ambition to that of Cap Posey, the deckhand who dreamed of becoming a steamboat engineer. Or Robert L. Vann, the editor who willed a local pamphlet into a national newspaper. Or Gus Greenlee, the racketeer who brought Satchel Paige to Pittsburgh, raided Josh Gibson from the crosstown Grays, and launched the "East-West Classic," the all-star baseball game that became the biggest sports event in black America. Or Billy Strayhorn, who composed a professional musical in his first year out of high school, before he ever met Duke Ellington. Or Evelyn Cunningham, who talked her way off the Women's Desk at the Courier by pitching a "widow angle" that convinced her editors to send her to cover the aftermath of a brutal racial murder in 1948 Georgia and launched Cunningham's career as a civil rights reporter.

As for the strains of working-class anger and frustration in so many of Wilson's plays, they also made sense when I considered the period in black Pittsburgh's history that shaped his worldview. For the flipside of the happy convergence that created "the 
Crossroads of the World" was the perfect storm that destroyed it almost overnight. In the late fifties, the city of Pittsburgh tore down the Lower Hill, the heart of black social and business life, in the name of urban renewal. In the late sixties, the riots that followed Martin Luther King Jr's assassination destroyed much of the Middle Hill and other black enclaves. The decline of the steel industry disproportionately devastated black folks, who couldn't get cheap loans to move to the suburbs like their white ethnic neighbors. Black flight took a toll, too, as ambitious, well-educated blacks who in the past would have stayed to become community leaders left and never came back-people like my father, Cleophaus Sylvester Whitaker, Jr., Westinghouse Class of 1952.

This connection between the historical destruction of the Hill and the artistic point of view of Wilson's plays was so evident that I entitled my last chapter "The Bard of a Broken World." Here's some of what I say about it. After describing the 1969 death of Jesse Vann, Robert L. Vann's widow and successor as publisher of the Courier, and the fact that Jesse had once appeared as a guest on the TV show This is Your Life, I write the following:

No one August Wilson came into contact with on the Hill in the late 196o's would ever have qualified for that distinction. They were the folks that the city's declining manufacturing economy and the downtown "Renaissance" had left behind: the steel and coal workers who had lost their jobs; the cooks and waiters who worked for minimum wage and tips; the garbage men and janitors who clung to lowly rungs on the city payroll; the hustlers and pushers who turned to selling pyramid scheme products and street drugs to get by. But the blues made Wilson yearn to hear their stories, and he went about finding places where he could eavesdrop on them. Wilson sat for hours in a booth at Eddie's Restaurant, nursing cups of coffee and scribbling down overheard conversations on napkins. He hung out at Pat's Place, a cigar store with a billiard table in the back where pensioners passed their days and where August came to be known as "Youngblood." Day after day, he ate lunch at a diner called Pan Fried Fish so that he could listen in on the conversations of gypsy cab drivers who worked out of a storefront "jitney station" next door-a collection of young hustlers and loquacious retirees who spent as much time telling tall tales and ribbing one another over games of checkers as they did answering the phone on the station wall that rang with calls for cheap rides around town.

It was these notes and memories, once Wilson moved to Minnesota in the late 1970's and began writing for the theater full-time, that became grist for his first Century Cycle play-a one-act version of Jitney-and the eight others that followed. Because Wilson littered those plays with so many references to actual addresses, businesses and figures in the Hill District, much as been written about how historically accurate he was, or wasn't, in those details. The family of the real Undertaker West, for example, complained about Wilson's heartless fictional character in Two Trains Running. Friends of the man who inspired the white butcher in the same play, the owner of Lutz Meat Market on Centre Avenue on the Hill, pointed out that in real life Lutz was a supporter of black rights who never would have welched on the debt of a ham.

But in Smoketown, I avoid such nit-picking because I think it misses the point. If you read Wilson's interviews and commentaries on his plays, it's clear that he never saw himself as a historical realist. He freely admits that he didn't do much factual research, or even attend much theater. Instead, he talks repeatedly about Aristotle's Poetics, which deals with the use of language to define character and dramatic structure to distill the tragedy and comedy of human existence. Wilson's essential genius, it seems to me, is in the way he took the everyday banter and street life of black Pittsburgh and elevated it to the level of universal poetry. He may have had his own controversial personal views about who was and wasn't authentically black, but he was enough of an artist to produce dramatic experiences that could be shared by people of all economic and racial backgrounds. In this sense, August Wilson was every bit the heir to the cultural tradition that produced Billy Strayhorn, Mary 
Lou Williams, Romare Bearden and so many other figures in my book, artists who took the specific cultural influences of Pittsburgh and used them to create work that transcends place and time and speaks to the entire world.

One final theme in Wilson's plays links him to the legacy I celebrate in Smoketown, and that's community. Wilson liked to say-provocatively, as usual-that relationship to community was what set the races apart. "The basic difference in worldview between blacks and whites can be expressed as follows," he once said. "Western culture sees man as being apart from the world, and African culture see him as a part of the world." It was why Wilson always said that his most famous play, Fences, with its solo "tragic hero," was his least favorite, while his favorite was Joe Turner's Come and Gone, that symphony of characters in a World War I era boarding house. At the end of my book, I repeat Wilson's observations because they echo the larger point I wanted to make about black Pittsburgh as a whole in its glory days. While I tell the story through individuals, I hope readers come away with a sense that the "Other Great Black Renaissance," as I call it, was made possible above all else by the dynamics of community-by the inspiration, fellowship and competitive motivation that its heroes and heroines received from each other.

Let me finish with more confession about my book-writing process. Until the very end, I didn't have a citation page-you know, that page at the front of books with a quote that is supposed to capture the essence of what you are about to read. I personally think citations have become somewhat of a cliché, so I didn't bother to include them. But just before the book was about to go to press, my editor informed me that the pagination had gotten screwed up, and the easiest way to solve the problem would be to add a citation page. So at the eleventh hour, I started scrambling for a suitable quote.

In the end, I found three. The first was from Lena Horne, who I write about in the book because she spent her early twenties in Pittsburgh. "You have to be taught to be second-class; you're not born that way," Lena said. The second, from Billy Strayhorn, was the plucky motto with which he bid friends goodbye. "Ever up and onward!" Strayhorn liked to say. And the third, thanks to theater critic Christopher Rawson, was from August Wilson. When King Hedley II, the eighth play in the Century Cycle, closed on Broadway in 2001, after mixed reviews and a two-month run that fell short of his earlier triumphs, Rawson interviewed his friend August for the Pittsburgh Post-Gazette. "You can only close if you opened," Wilson said philosophically. "We were there . . . you're not going to stay open forever."

"You can only close if you opened." What a terrific line! I thought. What a perfect way to sum up the spirit of ambition and creativity that I tried to capture in Smoketown! And what a fitting way for me to end this talk today. You can only close if you opened, and it's been my privilege and pleasure to help open this colloquium on the immortal legacy of August Wilson.

\section{Works Cited}

Whitaker, Mark. Smoketown: The Untold Story of Other Great Black Renaissance. Simon and Schuster. 2018. Print.

\section{Author Bio}

Mr. Mark Whitaker is an American author, journalist, and media executive. He was the editor of Newsweek magazine from 1998 until 2006, the first African-American to lead a national news magazine. From 2004 to 2006, Whitaker served as President of the American Society of Magazine Editors. He was Senior Vice President and Washington Bureau Chief 
A U G U S T W I L S O N J O U R N A L

\begin{tabular}{l|ll} 
Vol.1 & Spring 2019
\end{tabular}

for NBC News. From 2011 to 2013, he was Executive Vice President and Managing Editor of CNN Worldwide.

UI This journal is published by the University Library System of the University of Pittsburgh as part of its D-Scribe Digital Publishing Program and is cosponsored by the University of Pittsburgh Press. 